\title{
A.Gergely András
}

\section{BARTÓK-MODELL ÉS SZÍNTISZTA BARBÁRSÁGOK}

\section{JÁNOSI ZOLTÁN HANGJA AZ ANTROPOLÓGIA HANGSZERÉN}

\author{
DOI 10.35402/kek.2020.3.15
}

A barbárságok fogalma nem harmonizál Bartókkal, épp ellenkezőleg, az Allegro barbaro ritmikája is csupán a török vagy közel-keleti népzenei gyűjtés tónusait, no meg a „civilizálatlannak” tekintett Európán/Monarchián/nemzetállamon kívülinek minősített népeket idézte meg egykoron. A fogalom jelentésváltozásait vaskos tudástörténeti kötetben, mesteri esszében vagy sokszáz oldalas regényben lehetne körvonalazni (lásd mondjuk Péterfy Gergely Kitömött barbár-ját, ahol fényesen mutatkozik a látszólag idegen szerecsen tudásfölénye a bécsi arisztokrácia püffedt önteltségéhez képest) - de erre most itt sem tehetségem, sem terem nemigen volna részleteiben kitérni. Adott azonban egy mü, mely szerzője által irodalomantropológiának nevezve épp ilyen hangokon, hangszeren és lírai tónusban fogalmaz a bartóki modell és az irodalmi kánonok harmóniáiról. Az antropológus - maguk közt szólva - leginkább az lenne, aki az Embert körülményei, hite, megélhetése, világképe, eposzai és históriái komplex egészével, időben és térben is méltóképpen széles páston képes tanulmányozni, társadalmi terepen és nyelvi-szimbolikus jelrendszerek mögött is. De akkor mit kezdünk azzal, ha az irodalom müfajával összefüggésben teszi valaki kulcsfogalommá az antropológiát, a poézist, a drámai történéseket, a nyelvi rétegzettséget? Méghozzá nem antropológusként, hanem József Attila-díjas irodalomtörténészként, akinek ugyancsak alapszempontja lehet, hogy a méltánylandó irodalmi mű a kultúratudomány legjobb öröksége szerint az Embert körülményei, hite, megélhetése, világképe, eposzai és históriái komplex egészével, időben és térben is méltóképpen széles páston képes megjeleníteni, ahol erre a körülmények késztetést nyújtanak számára, vagy ahol nem közvetlenül az ember önpusztító mibenléte a fö témakör.

De itt, a münemek és műfajok határolatlan margóján mintha megrekedtem volna. Jánosi Zoltán kötete rekesztett meg, aki csodás líraisággal írt magyar irodalompoétikai esszékötetet és drámai színekben ábrázolható embertörténetet. Címében ugyan korlátozza a tartalmat és időt is, de ez csupán a formalitások műköltészete. A Barbárok hangszerén. Társadalom és antropológia a XX. századi irodalmunk életmüveiben olyan kötet, ${ }^{1}$ amelyben irodalmunk nagyjai és formaalkotói nem csupán embervoltukban jelennek meg, hanem az esszék (jobbára évfordulós tisztelgések, folyóiratcikkek, konferencia-előadások, gyüjteményes vagy tematikus kötetek írásai) átfogó életmü-rajzot is kínálnak, mégpedig legtöbbször az alkotó saját hangnemében-tónusában, szavainak fölidézésével, munkásságának legjava kiemelésével, világképének, hitének, léthelyzetének, sorsvállalásának legfinomabb rajzolataival. Vagyis hát a fentebbi tónusban akár antropológiai is lehetne mindez. Azaz: jószerével az is, de másféle.

Izgalmasan illeszkedik e könyv számunk címadó blokkjához, az azonosulás, az elkülönböződés, a távolság és a jelenvalóság, az emlékezet és a narratívák kérdésköréhez. A virtigli antropológus ugyanezzel találkozik, amikor a jelenkort szemléli, a múlt faggatása csak előtanulmányaihoz tartozik, illetőleg azokéhoz, akikkel beszélő-megfigyelömegjelenítő viszonyba kerül. Jánosi pedig jobbadán a múlt évszázad jellegadó szerzőit keresi fel, idézi meg, jellemzi, tolmácsolja, állítja ki, emlékezik rájuk. Muzealizálás nélkül, sőt. Minthogy azonban „a társadalomról” évszázados távolból beszélni rendre csak történész vagy tanító szokott, mintegy rajtakapjuk, hogy nem kortárs kulturális antropológiát kutat, hanem történetit, $s$ nem szociálantropológiát elsősorban, hanem irodalmit. Mindemellett (és ezenközben is) Jánosi már a kötet első írásában (Krúdyról) fölidézi azt a miliőt, amelyben az író létezett, amelyről írt, s amelybe mintegy „visszakerült” születése 125 . évfordulóján az emlékezet révén Nyíregyházán, egy emlékező ünnepségen, ahol kiválasztottsága és életműve valóságosan is keveredik az elbeszélő-mesélő-értelmező szerzői szándékot követő fölidézéssel. Majd József Attilával folytatja, az életmű kockakőnyi léptékével, a költő kockaköves életútjával, életeivel és halálaival, éhezésével és proletárjaival, befejezve az évfordulós esszét a kortárs /mai/ proletárok életével és halálaival, eladott kabátjával, fölvonuló seregletével, vonatlakó mivoltával. Majd Móricz jön, a felső-tiszavidéki falusi tompasággal, a bekecses uracsokkal, az egész

1 Holnap Kiadó, Budapest, 2010., 288 oldal 
poros-dohos-leigázott vidékiséggel, a gyarmattá vált kelettel, az úri murizó álnemességgel, az eladott magyarsággal és megszállt tartománnyal... Nem folytatom a sort, ezt nem megidézni, de olvasni kell. Míves, visszafogottan indulatos, felhangoltan árnyalt, szépecskén komponált szövegek sokasága. Társadalmi létbe szorult költészetről, irodalomról, nemzetbe szorult kietlen magyarságról, világképétől fosztott népekről, gyarmatosított hazáról. Az egész kötet minden írásában ez a kulcskérdés: milyen időkben éltek ezek a népek, milyen hagyományt és minták vittek tova, mibe buktak bele, $s$ hogyan lettek a „népiből” primitívvé, a „primitívből” barbárrá, amúgy mindenestül is.

Kétely ne érje, Jánosi nem csapott fel antropológusnak, de írókája olyan, mint a legméltóbbaké. Olyan, mint azok tollának néhány betüje, lelkének megannyi sóhaja, akikkel foglalkozik. Prózában, lírában, drámában kutat, világképet és mitikus történést, irodalomelméleti kontextusban jelentőséget és hatást, örökségben a maradékot és megújulást, a nemzeti sors önérték-mivoltának képleteit, a történeti botorság, vandalizmus, barbárság lenyűgöző összképét adva. Barbárok között olyanokra szíveskedjünk gondolni, mint Krúdy, Móricz, József Attila, Bartók Béla, Sütő András, Tamási Áron, Sinka István, Szilágyi Domokos, Lázár István, Csoóri Sándor, Nagy László, Ilyés Gyula, Lázár Ervin, Németh László... - csupa „primitív” művész... Köröttük-mellettük az örökség, az irodalmi kánonok, a hírnevek és sorsok, a történelem derűje és mocska, folklórszintézis és életviteli dráma, szimbolikus hagyományok követése és hagyománytalan szimbólumok intézményesítése, tájak és lírák évszázada, drámai társadalmak társadalmi drámái.

Vagyis hát, ha Jánosi „rekviemet” formál utcakövekből, melyeket Krúdy és József Attila városai, Móricz és Sütő stílusa, Ratkó József vagy Szécsi Margit lírája alakít járható ösvénnyé (mint az első esszécsokorban), vagy a kortárs próza „jajgató paradigmáit" faggatja Nagy László, Ilyés Gyula, Szilágyi Domokos, a népi írók vagy Szőcs Géza felfogásmódjai között, hogy a harmadik fejezet „virágot őrlő malom” Lázár Ervines, Ágh Istvános, Németh Lászlós, Csoóriból, Sütőből és a szlovákiai magyar irodalomból ihletett perspektívaváltások tájékán keresse ismét az Embert - akkor bizony valaminő antropológiát mível, csak nem utazott ezért óceániai szigetekre és posztmodern államelméletek hegyei közé. Nemcsak embereket, hitet, mítoszokat, létmódokat, világképeket, kultúraközi érintéseket faggat és formál is, hanem megérteni, megismerni, észrevenni, megszeretni is segít ezeket. Mintha antropológus lenne...

A kötet egyik kulcsfogalma, hívószava, bűvköre itt részben tudatosan nem került szóba. Az első írás volt, melyet (és melyért) kézbe vettem a kötetet, $s$ melynek felfedező tónusa nemcsak fülön csapott, de föl is bőszített. A fenti írótárból mintegy könynyedén kihallani mindazokat, akiknek ehhez a barbár világhoz úgy van közük, hogy annak nemcsak hallgatói, értői, de megtanulták az archaikum és a folklór mélyről jött „hangjait” újraírni, folytatni, átkomponálva is a barbár jelen hangrendjébe illeszteni. A „bartóki” örökségről, kompozícióról és hagyománykövetésről, megújításról és alázatról, az „eredet” fontosságát belátva a folytathatóság meredélyén is átmentve megőrzésről szól ez írása. Valahol kettősen az „archaikus saját” és az „egyetemes közös" közötti jelentéstulajdonítás lényegeként.

Ne higgyék el nekem, ha úgy tennék, mint aki képes egy tizenhat oldalas magvas esszéből két sorban kiemelni a „lényeget” - épp az antropológusok azok, akik menekülve kerülik az efféle társadalomképeket...! Itt Bornemisza Pétertől Bari Károlyig, Nagy Lászlótól Lázár Ervinig, Juhász Gyulától Csoórin át Kis Annáig vagy Mezey Katalinig, Kányádi Sándortól Petri Györgyig az áttekintés a színtiszta barbárságok megidézését követi keresztbe-kasul, a Cantata profana létértelmezésétől a primer mitologikus költészetig megannyi irányt véve szó esik e művészi egyetemesség gyökereiről, a „bartóki eszmekör" világlírába átívelő szivárványairól, az archaikus népiességről és a „remitologizáló” lírai örökségről, a „magyar sors $-s$ az ebben élő személyiség - aktuális létkérdéseit egzotikus inspirációk révén a müfaji inspirációkban gazdagító törekvésekről”, tehát „a Bartók-modell és annak szépirodalmi hatása illetve rokonsága" megannyi érintett alkotója sajátosságairól, végül is azzal a konklúzióval zárul: „De tökéletes válaszok, matematikai módon levezethető és megfogalmazható megoldások a Bartók-modell hatóerejéről bizonyára sohasem fognak megszületni" (123. old.).

A megfogalmazás szinte kézenfekvően nem a bartóki úton jár..., nem „a létértelmező művészi egyetemesség és a folklórból, az archaikus hagyományból kiemelt motívumok és világképelemek szintézisében" fogalmazza meg saját aspektusát (uo. 110.), s ezt Jánosi mintegy vállalja is. Irodalomesztétaként, irodalomtörténészként nem is lett antropológussá. De annyi bizonyosan és könnyen elmondható: a nemzeti történeti hagyományt akár Kölcseytől vezetve, a „multikulturális” 
összhatások és a prózafordulat révén önnön sorsára reflektáló szerzői én lázadásáig követett hagyaték „örökségesítésében” Jánosi nemcsak fényesen felmutatja a maga értékrendjét, de láthatóvá is teszi, hogy elkezdett játszani a „barbárok hangszerén”. Ennek pedig ha az egyetemességhez nincs is oly közvetlen köze, ám az alkotók köre, kikkel foglalkozik, már hangnemet és müformát választottak a kiváltképpen sikeres megjelenítéshez. Jánosi érdeme, hogy erre érzékenyen, írói finomsággal és ugyanakkor mindennemű gyarmatosítás-ellenes tónussal hívja föl figyelmünket. Ha nem is allegro barbaro-ban, de andante piano-ban. 